\title{
TOURMALINE (DRAVITE) FROM THE BOEHLS BUTTE ANORTHOSITE, IDAHO, U.S.A.
}

\author{
ANNA HIETANEN
}

\begin{abstract}
HIETANEN, ANNA, 1987: Tourmaline (dravite) from the Boehls Butte anorthosite, Idaho, U.S.A. Bull. Geol. Soc. Finland 59, Part 2, 91-95.

Tourmaline (dravite) from a layered two-plagioclase anorthosite in the Boehls Butte quadrangle, Idaho, has the following structural formula:

$\left(\mathrm{Na}_{0.55} \mathrm{Ca}_{0.17}\right)_{0.72}\left(\mathrm{Mg}_{1.96} \mathrm{Fe}_{0.57} \mathrm{Mn}_{0.01} \mathrm{Ti}_{0.04} \mathrm{~V}_{0.03} \mathrm{Al}_{0.47}\right)_{3.08} \mathrm{Al}_{6}\left(\mathrm{BO}_{3}\right)_{3.02} \mathrm{Si}_{5.98} \mathrm{O}_{18}(\mathrm{OH}, \mathrm{F})_{3.35}$. The indices of refraction are $\omega=1.647(1)$ and $\varepsilon=1.621(1)$, and the unit cell parameters are $a=15.9425(6)$ and $c=7.1883(3)$.

Key words: tourmaline, dravite, chemical composition, optical properties, cell dimensions, Boehls Butte, Idaho, United States.
\end{abstract}

Anna Hietanen: U.S. Geological Survey, Menlo Park, California 94025, U.S.A.

\section{Introduction}

Layers and small masses of tourmaline occur locally in the southernmost anorthosite body and neighboring metapelitic rocks in the Boehls Butte 15-minute quadrangle, Idaho (Hietanen 1963). Chemical analyses, optical properties, and unit-cell data show that the tourmaline is a variety of dravite. The name dravite was given by Tschermak (1885) to a magnesium-rich tourmaline found near the village of Dobrava in Unterdrauburg on the Drava River, Carinthia, Austria.

\section{Occurrence}

Near Boehls, Idaho, monomineralic layers and small masses of greenish-black dravite occur in layered anorthosite at the western end of a 20-km-long anticlinal body. At the eastern end of the body, quartzite layers interbedded with aluminum-silicate-rich schist that borders the anorthosite consist locally of 75 percent bluish gray-green dravite that has $\omega=1.640 \pm 0.005$ and $\varepsilon=1.620 \pm 0.005$ (Hietanen 1963, p. 18). Both dravite-rich rocks weather readily to a sandlike material that consists mainly of small crystals of tourmaline.

The host rock of the greenish-black dravite is a layered bimodal anorthosite that consists of white to light-gray layers, 10 to $100 \mathrm{~cm}$ thick, of andesine-bytownite or andesine-anorthite rock separated by 1 - to 5 -cm-thick dark layers. The dark layers contain either hornblende and biotite or three to six of the following minerals: biotite, muscovite, sillimanite, kyanite, andalusite, garnet, cordierite and rutile; they also contain the two plagioclases, $\mathrm{An}_{40-45}$ and $\mathrm{An}_{80-95}$, that make up the white-weathering layers (Hietanen 1963, 1984). Kyanite occurs in some plagioclase layers and in some hornblende-bearing layers. In a road cut near the former site of the Boehls 
Cabin several of the dark-colored layers, $1-2 \mathrm{~cm}$ thick but locally thickened to small masses $3-5 \mathrm{~cm}$ thick, are tourmaline.

The tourmaline, specimen 926, was collected in 1952 from a greenish-black friable tourmaline mass, $10-20 \mathrm{~cm}$ long and $4 \mathrm{~cm}$ thick, in a dark layer $700 \mathrm{~m}$ north of the former Boehls Cabin. This locality (long $115^{\circ} 54^{\prime} 30^{\prime \prime} \mathrm{W}$. and lat $46^{\circ} 52^{\prime} 50^{\prime \prime}$ N.) is now under 100 feet of water, flooded by the Dworshak Dam 50 miles down stream on the North Fork of the Clearwater River.

\section{Chemical composition}

Specimen 926 consists of small dark-green prisms $1-10 \mathrm{~mm}$ long and $0.1-1 \mathrm{~mm}$ thick. Under magnification the thin crystals are transparent and emerald green. The purified material was analyzed chemically by Sarah Neil, U.S. Geological Survey (Table 1). The sample was analyzed for $\mathrm{Fe}^{2+}$ and $\mathrm{Fe}^{3+}$ by Robert G. Johnson, U.S. Geological Survey, using Mössbauer spectroscopy. The results showed a single quadrupole douplet with an isomer shift of +1.10 and a quadrupole splitting of $2.49 \mathrm{~mm} / \mathrm{sec}$, which indicates that the only detectable species was $\mathrm{Fe}^{2+}$.

Calculation of the structural formula from the chemical analysis on the basis of $31(\mathrm{O}, \mathrm{OH}, \mathrm{F})$ (no. 1, Table 2) shows that this tourmaline is an iron-bearing dravite. The general formula for the schorl-dravite series can be written as follows: $\mathrm{Na}(\mathrm{Fe}, \mathrm{Mg})_{3} \mathrm{Al}_{6}\left(\mathrm{BO}_{3}\right)_{3} \mathrm{Si}_{6} \mathrm{O}_{18}(\mathrm{OH})_{4}$. The calculated formula of the analyzed material is:

$\left(\mathrm{Na}_{0.55} \mathrm{Ca}_{0.17}\right)_{0.72}\left(\mathrm{Mg}_{1.96} \mathrm{Fe}_{0.57} \mathrm{Mn}_{0.01} \mathrm{Ti}_{0.04} \mathrm{~V}_{0.03} \mathrm{Al}_{0.47}\right)_{3.08}$ $\mathrm{Al}_{6}\left(\mathrm{BO}_{3}\right)_{3.02} \mathrm{Si}_{5.98} \mathrm{O}_{18}(\mathrm{OH}, \mathrm{F})_{3.35}$. The structural formula shows a deficiency of the alkali ions and hydroxyl group and an excess of $\mathrm{Al}$ substituting for Mg. According to Foit and Rosenberg (1977), compositions that are alkali- and anion-deficient and $\mathrm{Al}$-rich are common among naturally occurring tourmalines. Such compositions involve a coupling of univalent and trivalent cations ac- cording to the equation $\left(\mathrm{H}^{+}, \mathrm{R}^{+}\right)+\mathrm{R}^{2+}=$ $\mathrm{R}^{3+}$.

Comparison of the chemical analysis of specimen 926 (no. 1, Table 1) with analyses of dravites in the literature shows that the Boehls dravite is similar to those that occur in aluminum-rich metapelites and metapsammites (Henry and Guidotti 1985; Mittwede, 1984) and in gneissic rocks and schist near ultramafic rocks (DuRietz 1935; Kunitz 1930; Deer et al. 1963). The total iron/magnesium ratio in the chemical analyses (nos. 1, 2 and 3, Table 1) is about 1:2 and in the corresponding calculated structural formulas (Table 2) it is close to $1: 3$. In contrast, the endmember dravites such as those from Dobrava and the Hirose Mine (nos. 4 and 5, Tables 1 and 2) contain very little iron.

\section{Optical properties and unit-cell}

Optical properties and unit-cell dimensions of naturally occurring tourmalines change with chemical composition. The indices of refraction and the unit-cell data of the Boehls dravite were determined by Richard C. Erd, U.S. Geological Survey. The indices of refraction measured in immersion liquids with sodium light are $\omega$ (brownish-green) $=1.647(1), \varepsilon$ (pale reddishbrown $)=1.621(1)$, and $\omega-\varepsilon=0.026(1)$. These are similar to the indices of refraction of the iron-bearing dravites from gneissic rocks (nos. 2 and 3 , Table 2), whereas the indices of refraction of the end-member dravites (nos. 4 and 5, Table 2) are lower. The unit-cell data, $a=$ 15.9425(6) and $c=7.1883(3)$, were obtained by a least-square refinement of the X-ray powder diffraction data scanned at $1 / 4^{\circ} 2 \theta$ per minute from $12^{\circ}-104^{\circ} 2 \theta$. The unit-cell dimensions of the Boehls dravite are practically identical with those given by Kitahara (1966) for the dravite from Hirose Mine, Japan (no. 5, Table 2) and very close to those of the end-member dravite from Dobrava (no. 4 Table 2) as given by the 
U.S. National Bureau of Standards (Swanson et al. 1964, p. 47-48).

\section{Discussion}

Epprecht (1953) redetermined $a$ and $c$ for a large number of analyzed tourmalines and compared his new data with that in the literature. When plotted against $c / a$, his new values for $a$ and $c$ show much less scatter than the old values and suggest a regular change in the unit-cell dimensions from schorl to dravite as well as from schorl to elbaite. From schorl to dravite, the iron content generally decreases, and with it $a$ decreases but $c$ increases in relation to increasing $c / a$.

Although the Boehls dravite contains a considerable amount of iron, its unit-cell dimensions are close to those of the end-member dravites. This suggest an influence on its unit cell of some other chemical factor in addition to iron. In their study of magnesium-rich tourmalines from East Africa, Schmetzer et al. (1979) concluded that in iron-free and iron-poor dravites the lattice constants $a$ and $c$ can be correlated with the number of $\mathrm{Al}$ cations in the formula. Their graph shows a regular increase in $a$ as the $\mathrm{Al}$ content decreases in the series: dravite with $\mathrm{Al}>6 \rightarrow$ dravite with

\section{References}

Deer, W. A.; Howie, R. A. \& Zussman, J., 1963. Rockforming minerals, Vol. 1 Ortho- and ring silicates. John Wiley \& Sons, New York, 333 p.

DuRietz, T., 1935. Peridotites, serpentines, and soapstones of northern Sweden, with special reference to some occurrences in northern Jämtland. Geol. Fören. Stock. Förh. 57, 2, 401, 133-260.

Epprecht, W., 1953. Die Gitterkonstanten der Turmaline. Schweiz. Mineral. Petrogr. Mitt. 33, 481-505.

Foit, F. F. \& Rosenberg, P. E., 1977. Coupled substitutions in the tourmaline group. Contrib. Mineral. Petrol. 62, $109-127$.

Henry, D. J. \& Guidotti, C. V., 1985. Tourmaline as a petrogenetic indictor mineral: an example from the staurolite-
$\mathrm{Al}=6 \rightarrow$ uvite with $\mathrm{Al}<6$. The change in $c$ is less regular but generally increases, with decreasing $\mathrm{Al}$.

The Boehls dravite has $6.47 \mathrm{Al}$ cations in the formula unit, but the unit-cell dimensions are practically identical with those of dravite from Hirose Mine, which has only 6.03 Al cations. Because $\mathrm{Ca}$ is low in these two dravites, it seems likely that the effect of the moderate amount of $\mathrm{Fe}$ was compensated by an excess of $\mathrm{Al}$ in the Boehls dravite, with the result that the unit-cell dimensions remained unchanged.

\section{Paragenesis}

The field relations near Boehls suggest that tourmaline takes the place of micas, hornblende, and aluminum-silicate minerals in some dark layers of the anorthosite exposed in an anticline. It seems that a local addition of boron into the dark layers - composed mainly of magnesiumrich dark minerals - gave rise to the crystallization of tourmaline. The origin of the boron is uncertain; it could be late magmatic or segregated from metasedimentary rocks and introduced into the micaceous layers in anorthosite and into quartzite layers in adjacent schist during a late stage of metasomatic metamorphism. grade metapelites of NW Maine. Am. Mineral. 70, 1-15.

Hietanen, A., 1963. Anorthosite and associated rocks in the Boehls Butte quadrangle and vicinity, Idaho. U.S. Geol. Surv., Prof. Paper 344-B, 78 p.

- , 1984. Geology along the northwest border zone of the Idaho batholith. U.S. Geol. Surv., Bull. 1608, 17 p.

Kitahara, J., 1966. On dravite (Mg-tourmaline) from the Hirose mine, Tottori Prefecture. J. Jap. Ass. Mineral. Petrol. Econ. Geol. 56, 228-233.

Kunitz, W., 1930. Die Mischungsreihen in der Turmalingruppe und die genetischen Beziehungen zwischen Turmalinen und Glimmern. Chem. Erde, 4, 2, 208-251.

Mittwede, S. K., 1984. Significance of tourmaline compositions from the inner Piedmont geologic belt of South Carolina. Southeastern Geol. 24, 4, 207-210.

Schmetzer, K.; Nuber, B. \& Abraham, K., 1979. Zur Kris- 
tallchemie Magnesium-reicher Turmaline (Crystal chemistry of magnesium-rich tourmalines). Neues Jahrb. Miner., Abh. 136, 93-112.

Swanson, H. E.; Morris, M. C.; Evans, E. H. \& Ulmer, L., 1964. Standard x-ray diffraction powder patterns. U.S.
Nat. Bur. Stand. Monogr. 25, 3, 64 p.

Tschermak, G., 1885. Lehrbuch der Mineralogie. A. Hölder, Wien, 597 p.

Manuscript received March 4, 1986. 